\title{
Totalisme, Totalitarisme og Demokrati i Nordiske Fængsler?*
}

\author{
Af Hans Jørgen Engbo, tidligere faengselschef $i$ Danmark og \\ direktør for Kriminalforsorgen i Grønland
}

\begin{abstract}
In the 1950s, sociologist Erving Goffman introduced the concept of the »total institution «, referring to an institution that served as » a place of residence and work where a large number of like-situated individuals, cut off from the wider society for an appreciable period of time, together lead an enclosed, formally administered round of life". Although more than half a century old, the concept remains widely used in contemporary penology, including penology in the Nordic countries. The current article questions what seems to be an almost automatic reliance on Goffman's theoretical framework in spite of the fact that modern Nordic prison regimes differ decisively from the US prison regimes that inspired Goffman's concept.

Following this, the article discusses whether Nordic prison regimes may be termed democratic or totalitarian. The conclusion is that Nordic prisons are formally democratic institutions, and after the rights-based paradigm shift in the 1960s and 1970s, even sub-stantive democracy has penetrated the prison gates. That said, the actual and legal conditions in Nordic (at least Danish) prisons do include the presence of certain totalitarian features.
\end{abstract}

\section{Indledning}

For mere end et halvt århundrede siden introducerede den canadisk-amerikanske sociolog Erving Goffmann begrebet totalinstitution om blandt andet fængsler (Goffman 1958 og 1967, s. 13). ${ }^{1}$ Begrebet er siden da blevet hyppigt anvendt i den kriminologiske forskning. Der har været - og er også i nutiden - en tendens til generelt og ret ukritisk at betegne fængsler som totalinstitutioner uden nogen nærmere analyse af det aktuelle fængselsregime sammenholdt med det USfængselsregime, som lå til grund for Goffmans analyse. Man ser meget sjældent en kriminologisk/sociologisk afhandling om fængselsforhold, som ikke - tilsyne-

* Title in English: Totalism, Totalitarianism and Democracy in Danish Prisons? 
ladende som et fagligt must - refererer til Goffmans analyse af totalinstitutionen (se fx Hammerlin 2008; Nielsen 2010; Lauritsen 2011; Minke 2012; Billund 2016).

Måske er det også begrebet totalinstitution, som (idé-associativt) fører til, at fængsler undertiden karakteriseres som totalitcere indretninger (se fx Hammerlin 2008, s. 174).

I det følgende vil Goffmans grundlæggende karakteristik af totalinstitutionen kort blive gengivet, og konceptets relevans for nutidens fængselsforståelse i de nordiske lande vil blive diskuteret, primært ud fra en juridisk vinkel i kombination med ca. 40 års praktisk tjeneste i danske fængsler.

Artiklen afsluttes med nogle betragtninger over begreberne demokrati og totalitarisme i relation til nordiske fængselsregimer. ${ }^{2}$ Disse betragtninger er beslægtet med den forudgående diskussion om totalisme, men har i øvrigt ingen sammenhæng med Goffmans institutionsanalyse.

\section{Goffmans totalisme ${ }^{3}$}

\subsection{Totalismens karakteristika}

Goffmann (1967, s. 9) definerede totalinstitutionen som »et opholds- og arbejdssted, hvor et større antal ligestillede individer sammen fører en indelukket, formelt administreret tilværelse, afskåret fra samfundet udenfor i en længere periode«. I sin beskrivelse af nogle væsentlige sider af totalinstitutionen fremhævede Goffman, at der i institutionen sker en nedbrydning af de barrierer, som i det moderne samfund normalt adskiller de tre områder søvn, leg og arbejde. Disse aktiviteter foregår i det frie samfund med forskellige meddeltagere, under forskellige myndigheder og uden en rationel helhedsplan. Goffman (1958, s. 314, og 1967, s. 13) uddybede denne karakteristik ved at pege på fire centrale kendetegn ved en totalinstitution:

1) Alle tilværelsens aspekter afvikles på samme sted og under samme myndighed;

2) alle dagliglivets aktiviteter afvikles sammen i en stor gruppe mennesker, som alle behandles ens og er sat til at gøre det samme i fællesskab;

3) alle dagens aktiviteter er nøje skemalagt, så den ene aktivitet på klokkeslæt afløses af den næste, og denne rækkefølge håndhæves oppefra gennem et system af formelle regler og en personalegruppe;

4) de forskellige påtvungne aktiviteter er indarbejdet i en enkel, rational plan, som angiveligt har til hensigt at opfylde institutionens officielle mål. 


\subsection{Goffmans referenceramme: 1950'ernes US-fcengselsregime}

For at kunne forstå indhold og rækkevidde af Goffmans totalinstitutionskoncept er det vigtigt at have kendskab til forholdene i de institutionstyper, blandt andet fængsler, som i 1950'erne udgjorde referencerammen for Goffmans koncept. Blandt de meget afgørende faktorer $i$ et fængselsregime er graden af indsattes retssubjektivitet, som derfor vil blive nærmere beskrevet i det følgende.

På Goffmans tid havde indsatte i US-fængsler i retlig forstand en slaveagtig status i kraft af den såkaldte »hands off doctrine«, som var klart formuleret i en dom afsagt i 1871 af Højesteret (Supreme Court) i staten Virginia. Dommen afviste at give en indsat almindelige borgerrettigheder:

»He is civiliter mortuus; and his estate, if he has any, is administered like that of a dead man. (...) The bill of rights is a declaration of general principles to govern a society of freemen, and not of convicted felons and men civilly dead. Such men have some rights it is true (...) but not the rights of freemen. They are the slaves of the State ... (Ruffin v. Commonwealth of Virginia, 62 Va 790, 1871).

De indsattes retsløse position som døde i retlig forstand (»civiliter mortuus«) var med enkelte variationer gældende i alle stater (Tappan 1954; se også Easton 2011, s. 20 ff). Selv om der var domstole, som havde taget skridt til at forlade hands off-doktrinen (fx Coffin v. Reichard, 143 F.2d 43, 8th Cir. 1944), blev den endnu i 1958 fulgt af USA's føderale højesteret (Supreme Court of the US): »In effect, we are asked to enter the domain of penology (...). This Court has no such power« (Gore v. United States, 357 U.S. 386, 1958). (Se Easton 2011, s. 36 ff)

Datidens pønologiske litteratur indeholder beskrivelser af den nærmest enevældige magt, som fængselschefen havde til at fastlægge regimet i det enkelte fængsel:

»It should be clearly understood that prison rules and punishment have nothing to do with the original sentence given the prisoner for his crime; they are solely to maintain whatever degree of routine order the warden thinks is desirable. Wardens who are more interested in the rehabilitation of their charges than in uniformity in all minute details of daily living introduce recreation, libraries, educational classes, and a certain freedom of communication. But these amenities are simply "privileges « that the warden allows; they are not rights that the prisoner can expect or demand. And if the prisoner disobeys regulations these privileges may be withdrawn at the warden's will. This situation places enormous power in his hands. When it is considered that most wardens are political appointees usually without training in either institutional administration or handling criminals, the danger of this concentration of power is apparent. Some wardens, by experience and personal attributes have developed into effcient administrators and humane leaders of the men under their care, but many more are both inefficient and ignorant of how to handle 
men either for an orderly but unoppressive prison life or a return to normal community living." (Cavan 1960, s. 436)

Hugh J. Klare, mangeårig sekretær for Howard League for Penal Reform, gav på samme tid en tilsvarende skarp - næsten karikaturagtig - beskrivelse af chefens magtposition i engelsk-walisiske fængsler:

»The Governor of a prison has powers which are acceptable in the father of small children but which would certainly be intolerable in the Prime Minister of a democratic country. However benevolent he may be, he is in fact a dictator, being at once chief administrator and judge, capable of punishing and rewarding those in his charge. « (Klare 1962. s. 85).

Klare tilføjede dog, at chefens magt ikke var ubegrænset, og at de centrale fængselsmyndigheder i en vis forstand skulle optræde som demokratriets vogtere ved at etablere og beskytte visse rettigheder og goder. Det afgørende er imidlertid, at det var myndighederne, som valgte, hvilke rettigheder, de ville begunstige de indsatte med. Det var rule of man og ikke rule of law, som herskede i datidens fængsler.

Det var disse retlige og faktiske forhold, som var Goffmanns referenceramme, da han anvendte begrebet totalinstitution i sin analyse af blandt andet fængsler, og disse forhold må nødvendigvis medregnes i forståelsen af begrebet, også når man anvender det i nutidens fængselsforskning, med mindre man udtrykkeligt om- eller nydefinerer begrebet.

Først i løbet af 1960-70'erne blev de indsatte anerkendt som borgere med rettigheder, jf. følgende udtalelse i en dom afsagt af USA's højesteret i 1974: »[A] prisoner is not wholly stripped of constitutional protections when he is imprisoned for crime. There is no iron curtain drawn between the Constitution and the prisons of this country.« (Wolff v. McDonnell, 418 U.S. 539, 1974).

Den ændrede retlige status for de indsatte synes dog ikke at have ført til afgørende brud med de totalistiske elementer i amerikanske fængsler (se Irwin \& Owen 2005).

Se nærmere om dette menneskeretlige paradigmeskifte nedenfor i afsnit 4 om demokratiske og totalitære fængselsregimer.

\subsection{Goffmansk totalisme i nutidens nordiske fangselsregimer?}

Kernen i Goffmans analyse har i Norden mistet kraft efter det rettigheds- og normalitetsbaserede paradigmeskifte i 1960-70, som indebar, at de indsatte opnåede anerkendelse som ligeværdige retssubjekter, idet de fik adgang til at udøve deres 
almindelige borgerlige rettigheder, i det omfang frihedsberøvelsen ikke i sig selv afskar dem herfra (se nærmere nedenfor i afsnit 4).

De fire ovenfor nævnte centrale karakteristika ved den goffmannske totalinstitution eksisterer stort set ikke længere i nordiske fængsler:

1) Alle tilværelsens aspekter afvikles ikke længere på samme sted og under samme myndighed. Mange indsatte, navnlig i åbne fængsler, har tilladelse til udgang og frigang til beskæftigelse og undervisning i både privat og offentligt regi i det frie samfund (straffuldbyrdelseslovens $§ 46$ og udgangsbekendtgørelsens § 44). ${ }^{4}$ I norske fængsler varetages uddannelse, helsetjeneste mm. af de respektive fagmyndigheder og ikke af fængselsmyndighederne (»importmodellen«, jf. Fridhov \& Langelid 2017). Tilsvarende er misbrugsbehandling i danske fængsler organiseret efter importmodellen (Løppenthin 2014). Flere steder varetages også skole- og biblioteksvirksomhed af eksterne samarbejdspartnere (Bentsen 2016, s. 24 f.). I det seneste halve århundrede har man $\mathrm{i}$ danske fængsler målrettet stræbt efter at skabe en fængselstilværelse, som så langt som muligt afspejler tilværelsen i det frie samfund (»normalitetsprincippet«, jf. Engbo 2017). I Danmark afsoner langt de fleste indsatte (80-90 procent) hele straffen i åbne fængselsafdelinger, hvor forholdene i ikke ringe omfang er tilrettelagt i naturligt samspil med det omgivende samfund (Engbo 2010, s. 180 ff; Fransen 2017). ${ }^{5}$

2) Dagligdagens aktiviteter afvikles ikke i store grupper; alle behandles $i k k e$ ens og er ikke sat til at gøre det samme i fællesskab. Tværtimod tilrettelægges den enkeltes fængselsophold individuelt med udgangspunkt i en personlig handleplan (straffuldbyrdelseslovens $\S 31$, stk. 2, og $\S 39$, stk. 2). De indsatte er i dagtimerne fordelt på en række mindre værksteder, skoleaktiviteter, behandlingstilbud mm., som de i nogen grad selv kan vælge imellem (se Schiøler $\S$ Dragsted 2017, s. 185 f.). Det tilstræbes, at arbejds- og skolevirksomhed mv. foregår på samme måde som tilsvarende virksomhed i det frie samfund. I fritiden kan de indsatte tilsvarende vælge blandt en række aktivitetstilbud - så vidt muligt svarende til fritidstilbud i det frie samfund (Betænkning nr. 1181/1989, s. 185).

3) Alle dagens rutiner er ikke mere skemalagte end daglige rutiner mange steder $i$ det frie samfund, bortset fra den rutinemæssige indlåsning i cellerne/stuerne om natten. Tværtimod er målet netop, at rammerne for de indsattes tilværelse i overensstemmelse med normalitetsprincippet skal minde mest muligt om rammerne for tilværelsen i det frie samfund (Engbo 2017, s. 336 f.; Minke 2012, s. 30). Som allerede nævnt foregår en mainstream-afsoning i Danmark i 
et åbent fængselsregime, som ligger meget fjernt fra det US-fængselsregime, som var genstand for Goffmans analyse. Men også regimet i lukkede fængsler i dagens Danmark afviger markant fra det goffmanske regime.

4) De forskellige aktiviteter er ikke indarbejdet i en enkel, rational plan til opfyldelse af et officielt mål for institutionen. Der er flere mål med aktiviteterne i et fængsel, men i god overensstemmelse med principperne om normalitet og ansvarlighed er det i høj grad den enkelte indsatte, som sætter målene for sine aktiviteter i arbejdstid og fritid, ganske som det sker blandt mennesker i det frie samfund (Straffuldbyrdelseslovens $\S 39$, stk. 2; Kriminalforsorgens Principprogram, s. 10 og 12).

Pladsen tillader ikke en detaljeret gennemgang af Goffmans eksempler på totalinstitutionens særlige indebyrd, men det kan slås fast, at forskellen mellem nutidens nordiske fængselsregimer og det mere end 50 år gamle US-fængselsregime er betragtelig. Her skal blot som et enkelt eksempel nævnes, at Goffmans bemærkning (1967, s. 20), om at tiden i en totalinstitution ikke kan anvendes til bl.a. uddannelse, normalt samkvem med kvinder og opdragelse af indsattes børn, står i diametral modsætning til nutidens nordiske fængselsregimer, som rummer målrettede (om end på nogle områder ret sparsomme) bestræbelser på - ikke mindst via mulighederne for udgang, besøg, telefonering og (begrænset) internetadgang - at tilbyde uddannelse og gode, naturlige kontakter med både partnere og børn. I danske fængsler har det siden 1973 været tilstræbt, »at de indsatte får tilbud om undervisning i samme omfang som landets øvrige borgere« (betænkningerne nr. 683/1973, nr. 1058/1986 og nr. 1181/1989). Se også Langelid (2017) om udviklingen af uddannelsestilbud i norske fængsler og Smith \& Jakobsen (2010) om bestræbelser på at styrke indsattes muligheder for at holde kontakt med deres børn og deltage i opdragelsen af dem.

Samlet set forekommer det ikke relevant for den pønologiske forskning i nutidens nordiske fængsler at anvende det goffmanske totalinstitutions-begreb som et altfavnende koncept. Dette koncept blev baseret på forholdene i amerikanske fængsler i 1950'erne, og siden da har man - ikke mindst i de nordiske fængsler arbejdet målrettet på at reformere fængslernes regimer bort fra et totalitets-regime hen imod et demokratisk normalitets-regime. Jones \& Fowles (2008, s. 104) betegner meget passende begrebet »totalinstitution « som lidt af et slagord (»a catchphrase «), som ofte bliver brugt ureflekteret (»unthinkingly«) om blandt andet fængsler.

Goffmans analyse har i en periode i midten af 1900-tallet været er en vigtig kilde for både kriminologer og praktikere til forståelse af fængslets funktion, men 
siden 1960-70'erne er det - i hvert fald i Norden - i første række historikere, som kan have faglig interesse i Goffmans skrifter.

Mens det således vil være vildledende at stemple nutidens nordiske fængsler som totalinstitutioner, kan delelementer i Goffmans koncept være relevante i visse fængsler eller fængselsafdelinger for visse indsatte eller grupper af indsatte samt i visse situationer og/eller i visse faser af et fængselsophold. Men en sådan anvendelse af konceptet er næppe heller i strid mod Goffmans egen indstilling, jf. følgende indledende bemærkning $\mathrm{i}$ hans beskrivelse af totalinstitutionen (1967, s. 12 f.):

»Inden jeg forsøger på at trække en generel profil frem af denne fortegnelse [over de berørte institutionstyper], vil jeg gerne nævne et begrebsmæssigt problem: ingen af de elementer, jeg vil beskrive, synes særegne for totale institutioner, og ingen af dem ser ud til at forefindes på enhver institution«.

Goffman (1967, s. 13) føjede hertil, at »[d]et karakteristiske ved totale institutioner er, at enhver af dem $i$ udprceget grad besidder mange af de anførte egenskaber «. ${ }^{6}$ Eftersom sådanne egenskaber - som påvist i denne artikel - kun $i$ minimal grad genfindes i nutidens nordiske fængsler, må disse således også efter Goffmans egen forudsætning falde uden for totalinstitutions-konceptet $\mathrm{i}$ dets originale udformning.

Blandt de totalistiske delelementer, som også kan findes i nutidens nordiske fængsler, er krcenkelser af personligheden. De konkrete typer af krænkelser, som Goffman omtalte (1967, s. 19 ff.) genfindes ganske vist kun i ringe grad, men det betyder ikke nødvendigvis, at de typer af krænkelser, som de indsatte udsættes for i nutidens nordiske fængsler, opleves som mindre følelige og mindre nedværdigende og psykisk belastende. Lauesen (1998, s. 98 ff.) opregner dels nogle oplevede pinefuldheder (»pains of imprisonment «, jf. Sykes 1971) udover selve frihedsberøvelsen, såsom mangel på besiddelse, mangel på heteroseksuelle forhold og mangel på tryghed, dels en række psykologiske og sociale konsekvenser som depression, ydmygelse, magtesløshed, udbrændthed, perspektivløshed og desocialisering. Der er næppe grund til at tro, at sådanne pinefulde konsekvenser af frihedsberøvelsen er mindsket i løbet af de tyve år, som er forløbet, siden Lauesen registrerede dem. Tværtimod må det antages, at pinefuldheden blandt de indsatte er vokset i styrke og omfang i takt med nye og flere kontrolindgreb og restriktioner (bl.a. flere urinprøver, flere person- og cellevisitationer samt mere isolation) som er indført i danske fængsler i de senere år, begrundet med bekæmpelse af radikalisering, terror, kriminel bandeadfærd, narkotika og illegale mobiltelefoner 
(se fx Justitsministeriets pressemeddelelse af 4. marts 2016 om 21 nye tiltag mod mobiltelefoner i fængsler). ${ }^{7}$ For mange indsatte er det et mærkbart savn at måtte undvære adgang til mobiltelefoni og internet (Smith 2012). I Norge har Hammerlin (2015, s. 149 ff.) i de seneste 30 år med faste mellemrum opdateret fangenes tapsliste, som indeholder en opregning af de »objektive betingelser, eksistensielle problemer og skadelidende konsekvenser et fengslet mennesket [i Norge] sliter med i fengselshverdagen«. Crewe (2009, s. 448 ff.) har beskrevet »the modern pains« oplevet af fængselsindsatte i England og Wales.

Når det gælder forholdet mellem indsatte og personale, kan dele af Goffmans analyse have begrænset gyldighed i visse af nutidens fængsler eller fængselsafdelinger, men generelt har regimer, opgaver og personalets (fængselsbetjentenes) rolle både i Norden og andre steder udviklet sig nærmest revolutionært i forhold til 1950'ernes US-amerikanske fængselsforhold (Nielsen 2011, s. 66 ff.; Coyle 2005, s. 86 ff.; Crewe 2009, s. 98 ff.; Liebling m.fl. 2011, s. 48 ff.). Goffmans observationer og analyse kan derfor også på dette felt i helt overvejende grad kun have interesse som historisk kilde.

Det skal bemærkes, at Goffman brugte betegnelsen »totalinstitution« om flere andre samfundsindretninger end fængsler, og at betragtningerne i denne artikel alene har handlet om begrebets anvendelse i fængselsverdenen. Noget kunne tyde på, at der i Danmark findes socialpædagogiske institutioner, hvis regimer snerper i retning af den goffmanske totalinstitution, og som tillige har klare totalitære træk (Da Silva 2018; Engbo 2008 og 2014).

\section{Demokrati og totalitarisme - begreberne}

Goffmans brug af begrebet totalinstitution kan være en medvirkende årsag til, at fængsler undertiden karakteriseres som totalitcere indretninger (se fx Hammerlin 2008, s. 174 og 2015, s. 132). Goffmann (1958, s. 314) betegnede selv forholdene på totalinstitutionerne som totalistiske (totalistic) og ikke som totalitære (totalitarian), men måske har han ikke lagt synderlig vægt på forskellen, eftersom forholdene i de amerikanske totalinstitutioner midtvejs i det 20. århundrede havde klare totalitære træk. Men kan nordiske fængslelsregimer i det 21. århundrede betegnes som totalitære? Eller demokratiske? Dette spørgsmål vil blive belyst i det følgende efter en nødvendig indledende begrebsafklaring.

\subsection{Demokrati-formelt og materielt}

»Ordet demokrati er af græsk oprindelse og betyder folkestyre. En afgørende bevæggrund til at vælge demokrati frem for andre styreformer er respekten for det enkelte individ og anerkendelsen af dets ret til størst mulig menneskelig udfoldel- 
se«. Sådan indledte den danske idéhistoriker og senere professor i filosofi Svend Erik Stybe (1964, s. 9) for 54 år siden en serie radioforedrag om demokrati, og dermed præsenterede han det liberale demokratis to hovedelementer, som ofte benævnes formelt demokrati og materielt demokrati. (Om begreberne formelt og materielt demokrati se Koch 2007 og Rytter 2009)

Med formelt demokrati menes folkestyre, som i vor del af verden er udmøntet som et repræsentativt demokrati, dvs. en styreform, hvorunder den politiske magt overvejende ligger hos en forsamling af folkevalgte. Politiske beslutninger, som er resultatet af en demokratisk besutningsproces, anses pr. definition som formelt demokratiske. Et af kernepunkterne i den politiske beslutningsproces er gennemførelse af frie og retfærdige valg til det styrende parlament. Dette markeres også i Den Europæiske Menneskerettighedskonvention (tillægsprotokol 1, art. 3), som lægger vægt på demokratiske forhold og forpligter staterne til »at lade afholde frie, hemmelige valg med passende mellemrum under forhold, som sikrer folkets frie meningstilkendegivelse ved valget af medlemmer til den lovgivende forsamling «.

Med materielt demokrati menes beskyttelse af visse grundlæggende samfundsmæssige og menneskeretlige værdier. Nogle af de centrale værdier er knyttet direkte til den formelle demokratiske styreform. Dette gælder de politiske friheder som ytrings-, forsamlings- og foreningsfrihed, som er vigtige forudsætninger for den frie meningsdannelse og dermed for befolkningens reelle deltagelse i den politiske beslutningsproces. Andre værdier er forbundet med de personlige fri- og rettigheder som religionsfrihed, ret til respekt for privatliv og familieliv og størst mulig personlig frihed. Beskyttelsen af disse værdier er et væsentligt led i det liberale demokrati, som vi hidtil har praktiseret i de nordiske lande. For de formelle demokratiske organer (myndighederne) indebærer kravet om materielt demokrati dels en begrænsning i magtudøvelsen, dels en forpligtelse til at realisere de nævnte værdier (Koch 2007, s. 341).

»Rule of law « (retsstatsprincippet) er et centralt element i det materielle demokrati. Statsmagten (regeringen og forvaltningsorganerne) er undergivet loven og ikke omvendt.

\subsection{Totalitarisme}

Totalitarisme som begreb knyttes normalt til det totale diktatur, som indebærer, at statsmagten (diktatoren) ud fra en opfattelse af at have uindskrænket myndighed stræber efter at herske over alle samfundets sfærer, også borgernes privatsfærer. Hvis vi skal anvende samme begrebsapparat, som blev brugt angående demokrati, kan vi tale om formel totalitarisme som betegnelse for den politiske beslut- 
ningsproces, som praktiseres i den totale diktaturstat, og materiel totalitarisme om den faktiske implementering (ved tvang) af det af statsmagten autoriserede værdisæt $\mathrm{i}$ alle dele af samfundet, inklusiv borgernes privatliv.

Men alt er ikke sort eller hvidt. Statsmagten (diktatoren og hans styringsapparat) i en totalitær stat kan i praksis undlade at bruge sin magt til at gribe ind i (dele af) borgernes privatsfærer, og der er også set eksempler på, at en diktator har gennemført værdimæssige reformer af menneskeretlig karakter. ${ }^{8}$ Det afgørende er dog, at statsmagten besidder den formelle magt til når som helst at stramme grebet om borgernes private forhold - og derved at praktisere materiel totalitarisme.

Omvendt kan man opleve, at flertallet i et demokratisk valgt parlament træffer beslutninger, som tvinger (grupper af) borgere ind under livsvilkår, som er baseret på et bestemt værdisæt og derved i praksis indfører totalitært prægede elementer i samfundslivet. Det materielle demokrati er netop i de seneste par årtier kommet under pres som følge af politiske indgreb fremprovokeret af international terrorisme, en voksende strøm af flygtninge og nye internationale spændinger. Vi er nu ganske paradoksalt gået over til at beskytte demokratiet med udemokratiske metoder. Hvis dette skal give mening, må vi konstatere, at demokratibegrebet $\mathrm{i}$ vor del af verden er under forandring. Vi fastholder det formelle demokrati, men materielt har vi i nogen grad erstattet det traditionellle liberale demokrati med et militant eller uliberalt demokrati (»illiberal democracy«).

\section{Demokratiske og totalitære fængselsregimer}

Begrebet »fngselsregime« skal i denne sammenhæng forstås i overensstemmelse med den definition, som the European Committee on Crime Problems (CDPC) under Europarådet har leveret:

»A prison regime consists of the set of factors and activities that constitute a prisoner's daily life and embraces not only a number of aspects of prison life (mention may be made here of prison management, prison work, instruction, vocational training, sport and leisure, social welfare and security) but also specific aspects closely linked with the outside world (e.g. prison leave, public understanding of prison problems, voluntary work, the opportunity for prisoners to keep in touch with the outside world through the mass media, respect for their rights and participation in elections). « (The European Committee on Crime Problems: Prison Regimes: Study Prepared by the Committee of Experts on Prison Regimes and Prison Leave CDCP (84) 8 rev addendum VI. Strasbourg: Counsil of Europe, 1986 1. Citeret efter Smit \& Snacken 2009, s. 176.)

Først må det slås fast, at på det formelle plan må fængslerne betegnes som demokratiske indretninger. Det moderne fængselskoncept blev ganske vist skabt under det enevældige monarki i første halvdel af 1800-tallet, men dets videreførelse og 
aktuelle udformning er resultatet af demokratiske (parlamentariske) beslutningsprocesser.

Vender vi os til det materielle plan med spørgsmålet om, hvorvidt fængselsregimet bygger på de grundlæggende samfundmæssige og menneskeretlige værdier, som kendetegner et demokratisk samfund, er svaret ikke helt enkelt. Man kan ikke afgøre, om danske fængsler i materiel henseende generelt er demokratiske eller totalitære. Forskellige fængsler og fængselsafdelinger har forskellige regimer. Man bliver nødt til for hvert enkelt fængselsregime at se på, hvilke konkrete faktorer og aktiviteter, der udgør rammerne for de indsattes dagligdag.

Der kan dog være god mening $\mathrm{i}$ at se på nogle overordnede linjer - retsgrundlaget, formulerede principper, værdier mv. - og vurdere disse i demokratisk/totalitært perspektiv. Indtil omkring 1970 ville det stride mod virkeligheden at betegne det grundlæggende regime i danske fængsler som demokratisk i materiel forstand. Vilkårene for de indsatte var fortsat præget af reminiscenser fra det proggressive, eller fremadskridende, system (Engbo 2010, s. 159 ff). De havde som udgangspunkt kun ganske få rettigheder. De kunne i løbet af afsoningen få tildelt (og frataget) såkaldte »begunstigelser« eller »goder«, hvis de havde gjort sig fortjent til det, men disse »behageligheder«, som de også blev kaldt, eksisterede primært som redskaber for fængselsledelsen til opdragelse og disciplinering af de indsatte (Fussing 1921, s. 31). Fængslets ledelse og personale besluttede og tilrettelagde i alt væsentligt beboernes daglige tilværelse. Regimet må betegnes som overvejende totalitært. Det materielle demokrati havde kun i beskedent omfang fundet vej gennem fængselsporten. Til trods for at de indsatte formelt ikke havde mistet deres stemmeret, var de reelt udelukket fra at deltage i folketingsog kommunalvalg, folkeafstemninger mv., idet der i fængslerne ikke var praktisk mulighed for stemmeafgivning.

I løbet af 1960-70'erne slog fængselssystemerne i store dele af den vestlige verden nogle gevaldige regimemæssige kolbøtter. De indsattes retsposition blev vendt på hovedet, så udgangspunktet nu blev, at de indsatte fik status som ligeværdige medborgere i samfundet med samme rettigheder som frie borgere (bortset fra retten til at bevæge sig frit). Disse ændringer må ses som et markant paradigmeskifte fra et overvejende totalitært til et overvejende demokratisk regime. Smit \& Snacken (2009, s. 40) taler om overgangen fra et autoritært/totalitært til et "post-autoritært« fængsel. Fængslernes retsorden blev nu ikke længere baseret på »rule of man«. Det var »rule of law « (retsstatsprincippet), som blev styrende for de indsattes retsposition. Det var retten (the law), som blev herskende; tidligere var det den fyrsteagtige fængselschef (the man), som ganske vist ikke helt uindskrænket, men dog inden for ganske vide rammer, kunne forme fængslets retsor- 
den efter sit eget hoved, jf. det ovenfor bragte citat fra Cavan (1960, s. 436) om chefens magt i amerikanske fængsler. Dette er en meget afgørende forskel på en demokratisk og en totalitær retsorden i et fængsel. Fangselschefen er underlagt loven og ikke omvendt. De indsattes tilværelse var ikke længere afhængig af privilegier eller »goder«, som fængselsledelsen diskretionært kunne begunstige dem med. Nu blev de af loven tildelt rettigheder (se også Lauesen 1998, s. 54). Den hollandske strafferetsprofessor, Constantijn Kelk, indførte begrebet retsborgerskab (rechtsburgerschap) om de indsattes retlige medborgerskab (refereret af Smit \& Snacken 2009, s. 69 f.).

Som tidligere nævnt blev de indsattes retsposition i US-amerikanske fængsler i løbet af 1960-70'erne ændret fra slave- til medborgerstatus, da domstolene forlod den såkaldte »hands off doctrine«. Tilsvarende skete andre steder, blandt andet i Canada (Regina v. Institutional Head of Beaver Creek Correctional Camp, ex parte MacCaud, 1969), i England-Wales (Regina v. Board of Visitors of Hull Prison, ex parte St Germain, 1979) og i Tyskland (BVerfGE 33,1 - Strafgefangene, 1972). I 1975 fastslog Den Europæiske Menneskerettighedsdomstol, at der ikke gjaldt særlige underforståede begrænsninger (implied limitations) for indsatte i retten til respekt for privatliv, familieliv og korrespondence (Golder v. the United Kingdom, App.no. 4451/70, dom 21. februar 1975). Dommen er efterfølgende lagt til grund for en tilsvarende forståelse af de øvrige konventionsrettigheder i artikel 9-11, blandt andet med denne formulering fra Domstolen: »Prisoners in general continue to enjoy all the fundamental rights and freedoms guaranteed under the Convention save for the right to liberty « (se fx Hirst v. the United Kingdom (No. 2), App.no. 74025/01, dom 6. oktober 2005, § 69). De indsatte fik hermed menneskerettigheder på lige fod med andre borgere.

I Danmark blev paradigmeskiftet indledt i slutningen af 1960'erne under Lars Nordskov Nielsens ledelse. ${ }^{9}$ Aude (1969, s. 165) beskrev skiftet således: »[D]et var tidligere udgangspunktet, at der skulle gives en begrundelse for at tilstå den indsatte en udfoldelsesmulighed, mens forholdet i dag er, at der skal gives grunde for at forholde den indsatte en sådan mulighed«.

Paradigmeskiftet indebar blandt andet, at de indsatte i 1970 fik fuld stemmeret, og i 1973 lovfæstede en ny bekendtgørelse om fuldbyrdelse af frihedsstraf de indsattes adgang til at udøve deres almindelige borgerlige rettigheder, i det omfang frihedsberøvelsen ikke i sig selv afskærer dem herfra (bekendtgørelse nr. 423/1973 om fuldbyrdelse af frihedsstraf $§ 19$, stk. 1).

I Norge var reformtanker i samme retning allerede i 1956 blevet formuleret af Komitéen til å utrede spørsmålet om reformer i fengselsvesenet (s. 60): 
»[S]traffullbyrdelsen [skal] ikke føre med sig flere og større innskrenkninger for den domfelte enn de som er nødvendig for å gjennomføre frihetsberøvelsen, oppretholde ro og orden i anstalten, og for mest mulig å sikre sig mot en skadelig påvirkning fangene imellom.«

Selv om disse tanker aldrig er kommet til direkte udtryk i norsk lovgivning, har de fået betydning i praksis. Ifølge Bronebakk (2012, s. 173 ff.) slog de dog først for alvor tydeligt igennem i 2007-08. I 1970 betegnede højesteretsdommer Trygve Leivestad da også fængselssamfundet i norske fængsler som »udemokratisk og autoritært« (Leivestad 1970, s. 106).

Reformerne medførte også øget medindflydelse for de indsatte. Begrebet »anstaltsdemokrati« blev taget i brug (Bondeson 1974, s. 454 ff.). I Danmark fik de indsatte i 1973 ret til gennem valgte repræsentanter (talsmænd) eller på anden måde at udtale sig om og øve indflydelse på generelle spørgsmål, der angår deres tilværelse i institutionen (bekendtgørelse nr. 423/1973 om fuldbyrdelse af frihedsstraf $\S 18$ ). Ved straffuldbyrdelseslovens ikrafttræden i 2001 blev denne ret yderligere manifesteret gennem detaljerede procedureregler for valg af talsmænd.

Udviklingen i fængslerne efter det nu snart 50 år gamle demokratiske paradigmeskifte har ofte fået etiketten »normalisering «, hvorved vi i Norden forstår, at de indsatte har samme borgerrettigheder, som frie borgere har (bortset fra bevægelsesfriheden), og at rammerne for tilværelsen i fængslerne så langt som muligt skal nærme sig rammerne for tilværelsen for mennesker i det frie samfund (se nærmere Engbo 2017, s. 327 ff., om nordisk forståelse af begrebet »normalisering«). Bronebakk (2012, s. 176) er for norsk kriminalomsorgs vedkommende på samme linje, mens Y. Hammerlin (2012, s. 40, og 2018, s. 260 f.) ved også at tale om at behandle og bearbejde fanger til »normalitet« arbejder med et flertydigt indhold $\mathrm{i}$ begrebet.

\section{Demokratisk fængselsregime med totalitære træk}

Konklusionen må således være, at det materielle demokrati i vore dage som principielt udgangspunkt eksisterer i fængslerne i samme udstrækning som i det frie samfund. Anerkendelsen af rule of law og menneskerettigheder i fængslerne er centrale faktorer i det materielle demokrati. Det vil derfor være forkert at påstå, at det danske fængselsregime grundlæggende er totalitært. Hermed være dog ikke sagt, at der ikke kan være elementer i fængselsregimet, som bryder mod demokratiske værdier, og som måske oven i købet kan antage totalitær karakter.

Først må det slås fast, at den magt, som fængselsmyndighederne har hjemmel til at udøve, alene er knyttet til selve den fysiske gennemførelse af frihedsberøvelsen. Enhver magtanvendelse - fysisk såvel som ikke-fysisk og direkte såvel 
som indirekte - som udøves med andre formål end gennemførelse af frihedsberøvelsen (med tilhørende opretholdelse af orden og disciplin), må derfor anses for illegitim, bortset fra sådanne former for magtanvendelse, som offentlige myndigheder har hjemmel til at udøve over for alle samfundsborgere. Der er navnlig grund til at være på vagt over for formynderisk magtudøvelse i resocialiseringsøjemed (Engbo 1991; Hammerlin 2008, s. 190 ff). Begrebet »resocialisering« ses ofte brugt i Kriminalforsorgen, selv om det er et diffust begreb, hvis anvendelse optræder med flertydig forståelse. I et demokratisk samfund er det betænkeligt at forstå opgaven sådan, at det er fængslets opgave at resocialisere den indsatte - en ofte brugt talemåde. Det bør kun være den indsatte selv som autonomt individ i et demokratisk samfund, som kan »resocialisere« sig. Staten, dvs. ikke alene fængselsmyndighederne, men også andre offentlige myndigheder, bør hjælpe, støtte og facilitere denne proces, man det vil snerpe i totalitær retning, hvis staten egenmægtigt »stjæler« opgaven og gør individet til en slags råvare, som man bearbejder ud fra nogle af statsmagten valgte værdier. I et demokratisk samfund skal myndighederne arbejde for mennesker og ikke med mennesker, som det ellers ofte noget floskuløst udtrykkes (Goffmann 1967, s. 60 ff.).

Forskellen kan belyses ved at sammenligne ordvalgene i den danske og den grønlandske formulering af Kriminalforsorgens vision:

Vision for Kriminalforsorgen i Danmark:

»Vi bringer mennesker sikkert videre til et liv uden kriminalitet«.

Vision for Kriminalforsorgen i Grønland:

»Vi hjolper mennesker sikkert videre mod et liv uden kriminalitet«. ${ }^{10}$

I Grønland vil Kriminalforsorgen hjoelpe den indsatte videre, og derved respekterer man, at den indsatte selv er ansvarlig for opgaven. Den indsatte er ansvarlig for sin egen resocialisering. I Danmark vil man bringe den indsatte videre, og denne ordlyd signalerer principielt, at Kriminalforsorgen tager ansvaret for (resocialiserings)opgaven fra den indsatte, hvilket selvfølgelig legitimt kan ske efter dennes anmodning, men hvis det er tanken, at det også skal kunne ske uanmodet og måske oven i købet tvangsmæssigt, er der tale om statsformynderi med totalitære undertoner.

Blandt de politiske friheder er det værd at notere, at i Danmark har de indsatte ikke fuld ytringsfrihed på lige fod med andre borgere. Fængselsmyndighederne kan forbyde de indsatte at udtale sig til medierne på grundlag af et så diffust krite- 
rium som hensynet til retsfølelsen, og fængselschefen har i vid udstrækning ret til at gennemlæse blade, som de indsatte udgiver, og at bortcensurere bestemte artikler, hvis indholdet groft forulemper enkeltpersoner (straffuldbyrdelseslovens $\S 59$, stk. 2, og § 37, stk. 3; se nærmere Engbo \& Smith 2012, s. 181 ff.) - en censur, som er på kant med grundlovens $\S 77$, og som forekommer overflødig, idet man burde kunne klare sig med injurie- og medielovgivningen, herunder de presseetiske regler.

Et yderligere element i dansk fængselsret med tvivlsom demokratisk forankring er procesordningen $i$ disciplincersager. Medens man i den almindelige straffeproces siden 1919 har fulgt en akkusatorisk procesordning, har man i disciplinærstraffeprocessen fastholdt en procesordning på inkvisitorisk grundlag. Formelt kan det hævdes, at man blot følger den almindelige forvaltningsproces, som indebærer, at forvaltningen - her i skikkelse af en forhørsleder - både undersøger sagen og træffer afgørelse, jf. det såkaldte undersøgelsesprincip. Men en disciplinærsag har så klare lighedspunkter med en straffesag, at det ville være naturligt at læne sig op ad de straffeprocessuelle spilleregler, således som De Europæiske Fængselsregler anbefaler i regel 59. Heri kræves blandt andet, at indsatte, der anklages for en disciplinær forseelse, skal

- underrettes omgående og detaljeret om arten af anklagerne mod dem,

- have tilstrækkelig tid og de nødvendige faciliteter til at forberede deres forsvar,

- have ret til at forsvare sig, enten selv eller med juridisk bistand, hvis dette er nødvendigt for at sikre, at retfærdigheden kan ske fyldest,

- have ret til at kræve vidner indkaldt og afhøre dem eller få dem afhørt på deres vegne.

Disse krav opfyldes ikke i den danske procesordning i disciplinærsager (Engbo \& Smith 2012, s. $281 \mathrm{ff}$ ). Den indsatte har ganske vist ret til at møde med bisidder til disciplinær afhøring, men han/hun må selv betale for en advokat, så juridisk bistand er reelt en illusorisk mulighed, som kun meget sjældent udnyttes. Danmark kunne med demokratisk fordel tage ved lære af andre landes retssystemer på dette område, herunder ikke mindst den engelske-walisiske procesordning i disciplinærsager. (Prison Service Instruction (PSI) 2011-047 Prisoner Discipline Procedures. Se også Coyle 2005, s. 143 ff.)

Udviklingen i danske fængsler i de senere år har i flere henseender antastet de demokratiske værdier, dels i forbindelse med en omfattende reorganisering af Kriminalforsorgen, dels i bestræbelserne for at forebygge radikalisering, ekstre- 
misme, terrorisme og kriminel bandeadfærd i fængslerne. Udviklingen har blandt andet medført

- svækket klageadgang for de indsatte

- skærpede afsoningsvilkår for udvisningsdømte (udelukkelse fra beskæftigelse ved uddannelse, undervisning eller programvirksomhed)

- stærkt udvidet brug af isolation som disciplinærstraf

- begrænsning af fællesskab (kaldet »sektionering «) for visse grupper af indsatte

- elektronisk overvågning af visse indsatte ved prøveløsladelse og udgang

- indgreb i bandemedlemmers adgang til besøg, brevveksling, telefonering, udgang og prøveløsladelse.

Visse af de nævnte regimemæssige indgreb kan nærme sig menneskeretskrænkelser. Den Europæiske Menneskerettighedsdomstol har understreget, at forbuddet $\mathrm{i}$ EMRK art. 3 mod tortur og anden umenneskelig eller nedværdigende behandling eller straf (»one of the most fundamental values of democratic societies«) ikke kan fraviges $»$ notwithstanding the existence of a public emergency threatening the life of the nation«, og Domstolen fortsætter: »Even in the most difficult of circumstances, such as the fight against terrorism, and irrespective of the conduct of the person concerned, the Convention prohibits in absolute terms torture and inhuman or degrading treatment and punishment « (A. and Others v. the United Kingdom, app. no. 3455/05, dom 19. februar 2009, § 126. - Se også Easton 2011, s. 11 ff.).

\section{Det materielle demokratis dynamik}

Det skal understreges, at man ikke én gang for alle kan fastslå, hvad materielt demokrati indebærer. Den almindelige samfundsudvikling skaber også udvikling af det materielle demokrati. Eksempelvis nævnes, at elektroniske kommunikationsmidler - og med dem de sociale medier - $\mathrm{i}$ vor tid har indtaget en ganske betydningsfuld plads både i hverdagslivet og i det politiske liv. Den Europæiske Menneskerettighedsdomstol har udtalt, at internetadgang spiller en vigtig rolle $\mathrm{i}$ menneskers daglige tilværelse og har anerkendt, at adgangen til at søge information via internettet er omfattet af EMRK artikel 10 (Kalda v. Estonia, 2016; Jankovskis v. Lithuania, 2017). Hvis myndighederne skal opretholde demokratiske forhold i fængslerne, må man udvikle livsrammerne, mulighederne og rettighederne for de indsatte i takt med den tilsvarende udvikling for borgere i det frie samfund. I denne henseende synes danske fængsler at bevæge sig mod et ac- 
celererende demokratisk underskud med en (politisk bestemt) mere og mere restriktiv holdning til indsattes adgang til internet, mobiltelefoni mm. (Smith 2012; Jørgensen \& Smith 2016).

Der er dynamik i det materielle demokrati, og det gælder også i fængslerne, som ikke længere (som på Goffmans tid) har karakter af isolerede enklaver, delvis med egne retsordener. Fængselspraksis, som i går var forenelig med demokratiet, kan i dag have antaget totalitær karakter, hvis man i fængslerne har forsømt at følge med samfundsudviklingen på områder, som angår det materielle demokrati.

\section{Noter}

1. Goffman gennemførte sit feltarbejde på en lukket psykiatrisk afdeling, men han overførte resultaterne til alle institutionstyper med samme karakteristika, og analysen er siden blevet flittigt brugt i fængselsforskningen.

2. Artiklen er en redigeret og noget udvidet udgave af forfatterens artikel »Totalitære og demokratiske fængselsregimer« i: I.M. Fridhov, B. Johnsen \& D. Bakken (red.): Festskrift til Yngve Hammerlin. Lillestrøm: Kriminalomsorgens høgskole og utdanningssenter, KRUS, 2017, s. 51-57.

3. Ordet totalisme (eng.: totalism) anvendes i nordisk sproglig praksis med vekslende betydning, lige fra total afholdenhed fra alkohol til totalitær styreform for et samfund. I denne artikel dækker ordet over de særlige træk (»totalistic features«), som Goffman (1958, s. 314) tillagde visse samfundsindretninger, som han herefter betegnede totalinstitutioner (»total institutions «). I Svenska Akademins ordbok forklares begrebet totalism med ordene: »åskådning som kännetecknas av helhetssyn (på individ o. samhälle)«, hvilket næppe falder helt ved siden af Goffmans brug af ordet; totalinstitutionen dominerer og administrerer helheden i beboernes tilværelse. (Hvis denne administration tillige indebærer knægtelse af individets demokratiske rettigheder, foreligger der materiel totalitarisme og ikke kun totalisme, jf. afsnit 3.2).

4. I årene 2012-2016 blev der i danske fængsler og arrester gennemsnitlig gennemført 17.904 udgange årligt til arbejde eller uddannelse (frigang). Kilde: Kriminalforsorgens statistik 2016, tabel 4.2.

5. Ifølge tabel $1 \mathrm{i}$ Kriminalforsorgens statistikberetning for 2003 blev 7.040 fængselsdømte indsat i åbne fængsler, medens 942 blev indsat i lukkede fængsler - svarende til henholdsvis 88 procent og 12 procent. Siden da er denne tabel beklageligvis - angiveligt af tekniske grunde - udgået af Kriminalforsorgens løbende statistikføring. Det må antages, at fordelingen af de fængselsdømte mellem åbne og lukkede fængselspladser ikke har rykket sig væsentligt siden 2003, selv om nogle af de dømte (2.319 i 2016, jf. Kriminalforsorgens Statistik 2016, tabel 2.9), som traditionelt ville høre hjemme i åbne fængsler, siden 2005 er sat til afsoning på bopælen med elektronisk fodlænkekontrol. Fordelingen mellem åben og lukket kapacitet var den samme i 2016 som i 2003, hvis der korrigeres for fodlænkepladser.

6. Kursiveret her. 
7. http://justitsministeriet.dk/nyt-og-presse/pressemeddelelser/2016/justitsminister-soerenpind-praesenterer-21-tiltag-mod (læst 11. september 2018).

8. Et eksempel er reformbølgen i Danmark-Norge i 1700-tallet (ophævelse af al censur og indførelsen af fuld trykkefrihed, afskaffelse af tortur inden for retsvæsenet, forbedring af forholdene for fæstebønder, afskaffelse af mange privilegier osv.) gennemført af gehejmekabinetsminister Johann Friedrich Struensee, som reelt fungerede med en diktators beføjelser.

9. Lars Nordskov Nielsen var direktør for fængselsvæsenet i årene 1967-71.

10. Kriminalforsorgen i Grønland, som hører under det danske justitsministerium, blev i 2013 pålagt at kopiere den danske kriminalforsorgs vision og strategiplan, dog med nødvendig tilpasning til de særlige grønlandske forhold. Denne tilpasning indebar blandt andet det ændrede ordvalg i formuleringen af visionen for den grønlandske kriminalforsorg.

\section{Litteratur}

Aude, C. (1969): Fra feengsel til frihed. 3. udgave. København: Det danske forlag.

Bentsen, D.S. (2016): Mere kompetencegivende og målrettet uddannelse i fængslerne. En evaluering af satspuljeprojektet »Styrket uddannelse til indsatte«. København: Direktoratet for Kriminalforsorgen, Koncern Resocialisering, Analyse og Evaluering.

Betcenkning $n r$. 1058/1986 om Arbejde, Undervisning og Fritid. Afgivet af et udvalg nedsat af Direktoratet for Kriminalforsorgen.

Betcenkning $n r$. 1181/1989 om en lov om fuldbyrdelse af straf $m v$. Afgivet af en arbejdsgruppe nedsat af Straffelovrådet.

Betcenkning $n r$. 683/1973 om undervisning, erhvervsuddannelse og fritidsaktiviteter for indsatte i fcengselsveesenets anstalter. Afgivet af det af Justitsministeriet den 29. marts 1968 nedsatte udvalg.

Billund, L. (2016). Arbejde og samarbejde i tvangsbårne relationer: Et relationsteoretisk perspektiv på faengselsbetjentfaget. Aalborg Universitetsforlag. Ph.d.-serien for Det Humanistiske Fakultet, Aalborg Universitet, DOI: 10.5278/vbn.phd.hum.00043

Bondeson, U. (1974): Fången i fångsamhället. Malmö: P.A. Norstedt \& Söners Förlag.

Bronebakk, K.B. (2012): Frihet og fordommer. I: S. Olsen (red.): Virker straff?, s. 173 ff. Oslo: Scandinavian Academic Press.

Cavan, R.C. (1960): Criminology, second edition. New York: Thomas Y. Crowell Company.

Coyle, A. (2005): Understanding prisons. Key issues in policy and practice. Maidenhead: Open University Press.

Crewe, B. (2009): The Prisoner Society. Oxford: Oxford University Press.

Crewe, B., A. Liebling \& S. Hulley (2015): Staff Prisoner Relationships, Staff Professionalism, and the Use of Authority in Public- and Private-Sector Prisons. I: Law \& Social Inquiry, Vol 40, Issue 2, s. 309-344.

Da Silva, L.H.P (2018): Kommunebarn. Aarhus: Forlaget DreamLitt.

Easton, S. (2011: Prisoners' Rights. Oxon: Routledge.

Engbo, H.J. (1991): Demokratiske og etiske fordringer til fængslernes magtudøvelse. I: Nordisk Tidsskrift for Kriminalvidenskab, s. $225 \mathrm{ff}$.

Engbo, H.J. (2008): Tugtelsespædagogik eller straf. Kronik i Politiken den 29. november. 
Engbo, H.J. (2010): Fængselsfaglige udfordringer gennem 100 år - belyst gennem udviklingen i dansk fængselsret 1910-2010. I: M. Hinze (red.): Direktoratet for Kriminalforsorgen 19102010, s. 153 ff. København: Direktoratet for Kriminalforsorgen.

Engbo, H.J. (2014): Menneskeretlige rammer for kriminalretlige foranstaltninger mod unge. I: Rapport fra NSfKs 56. forskerseminar, Skarrildhus, Danmark 2014, s. 69 ff. Nordisk Samarbejdsråd for Kriminologi.

Engbo, H.J. (2017): Normalisation in Nordic Prisons - From a Prison Governor's Perspective. I: P.S. Smith \& T. Ugelvik (red.): Scandinavian Penal History, Culture and Prison Practice. Embraced By the Welfare State? s. 327 ff. London: Palgrave Macmillan.

Engbo, H.J. \& P.S. Smith (2012): Fangsler og menneskerettigheder. København: Jurist- \& Økonomforbundets Forlag.

Fransen, P: (2017): The Rise of the Open Prisons and the Breakthrough of the Principle of Normalisation from the 1930s Until Today. I: P.S. Smith \& T. Ugelvik (red.): Scandinavian Penal History, Culture and Prison Practice. Embraced By the Welfare State? s. 81 ff. London: Palgrave Macmillan.

Fridhov, I.M. \& T. Langelid (2017): Importmodellen i norsk fengselsvesen. I: Nordisk Tidsskrift for Kriminalvidenskab, s. $259 \mathrm{ff}$.

Fussing, T. (1921): Betcenkning angaaende Bestemmelser om Frihedsstraf og med Frihedsberøvelse forbundne Sikkerhedsforanstaltninger. København.

Goffmann, E. (1958): The Characteristics of Total Institutions. I: Symposium on Preventive and Social Psychiatry, Walter Reed Army institute of Research, Washington D.C., 15-17, April 1957, s. 312 ff. Washington: Government Printing Office.

Goffmann, E. (1967): Anstalt og menneske. Den totale institution socialt set. Dansk oversættelse af »Asylums« (1961). Paludans Fiol-bibliotek. Jørgen Paludans Forlag.

Hammerlin, Y. (2008): Om fangebehandling, fange- og menneskesyn $i$ norsk kriminalomsorg $i$ anstalt 1970-2007. Doktorafhandling. Universitetet i Oslo.

Hammerlin, Y. (2012): En fange er en fange - et fengsel er et fengsel. Dikotomien i fangebehandlingen fra 1950-tallet fram til i dag. I: S. Olsen (red.): Virker straff? s. 39 ff. Oslo: Scandinavian Academic Press.

Hammerlin, Y. (2015): Et fengsel er et fengsel, men ... I: Psyke \& Logos, 2015, Årgang 36, nr. $1, \mathrm{~s} .29 \mathrm{ff}$.

Hammerlin, Y. (2018): Materiality, Topography, Prison and 'Human Turn' - A Theoretical Short Visit. I: E. Fransson, F. Giofrè \& B. Johnsen (red.): Prison Architecture and Humans, s. 241. Oslo: Cappelen Damm Akademisk.

Irwin, J. \& Owen B. (2005): Harm and the contemporary prison. I: A. Liebling \& S. Maruna (red.): The Effects of Prisonment, s. 94 ff. Collumpton: William Publishing.

Jones, K. \& Fowles, A.J. (2008): Total institutions. I: J. Johnson \& C. DeSouza (red.): Understanding Health and Social Care: An Introductory Reader, s. 103 ff. London: Sage Publocations Ltd.

Jørgensen, R.F. \& P.S. Smith (2016): Fængslet og den digitale kløft - Frihedsberøvelse, internetadgang og menneskerettigheder. I: EU-ret \& menneskeret, Årg. 23, nr. 2, s. 7 ff.

Klare, H. (1962): Anatomy of Prison. Harmondsworth, Middlesex: Penguin Books Ltd.

Koch, H. (2007): Det materielle demokrati - rettigheder og værdier. I: B. Diestelkamp m.fl. (red.): Liber amicorum Kjell A Modéer, s. 335 ff. Lund: Juristförlaget. 
Kriminalforsorgens Principprogram. København: Direktoratet for Kriminalforsorgen, 1998.

Langelid, T. (2017): The Development of Education in Norewgian Prisons. I: P.S. Smith \& T. Ugelvik (red.): Scandinavian Penal History, Culture and Prison Practice. Embraced By the Welfare State? s. 225 ff. London: Palgrave Macmillan.

Lauritsen, A.M. (2011): Anstalten - frihedsberøvelse i Grønland. Ilisimatusarfik, Grønlands Universitet.

Leivestad, T. (1970): Noen etiske synspunkter ved behandlingen av kriminelle. I: A. Bratholm, K. Bødal, E. Egeland, T. Leivestad, P.A. Holter \& T. Mathiesen: Du må ikke tåle ... Seks innlegg om kriminalreform, s. 91 ff. Oslo - Bergen - Tromsø: Universitetsforlaget.

Liebling, A., D. Price \& G. Shefer (2011): The Prison Officer. Oxon: William Publishing.

Løppenthin, N. (2014): Arsrapport vedr. Misbrugsbehandling. København: Direktoratet for Kriminalforsorgen, Center for Straffuldbyrdelse, Koncern Resocialisering.

Minke, L.K. (2012): Indsattes organisering af selvforplejning - spisestuen som showroom. I: Retfaerd, nr. 2, s. 137.

Nielsen, M.M. (2010): Miraculous Metamorphoses: On Staff-Prisoner Relationships in a Danish Prison. København: Sociologisk Institut, Københavns Universitet.

Rytter, J.O. (2009): Om begrebet »demokrati« i Menneskerettighedsdomstolens praksis. I: J. Christoffersen \& M.R. Madsen (red.): Menneskerettighedsdomstolen - 50 års samspil med dansk ret og politik, s. 175 ff. København: Thomsen Reuters.

Schiøler, J. \& A. Dragsted (2017). Straffuldbyrdelsesloven med kommentarer. København: Jurist- og Økonomforbundets Forlag.

Smit, D.v.Z. \& S. Snacken (2009): Principles of European Prison Law and Policy. Penology and Human Rights. Oxford: Oxford University Press.

Smith, P.S. \& J. Jakobsen (2010): Når straffen rammer uskyldige. Børn affcengslede i Danmark. København: Gyldendal.

Smith, P.S. (2012): Imprisonment and Internet Access - Human Rights, the Principle of Normalization and the Question of Prisoners Access to Digital Communications Technology. I: Nordic Journal of Human Rights, no. 4, s. 454 ff.

Stybe, S.E. (1964): Demokratiets principper. København: Munksgaards Forlag.

Sykes, G.M. (1971): The Society of Captives: A Study of a Maximum Security Prison. Princeton, NJ: Princeton University Press.

Tappan, P.W. (1954: The Legal Rights of Prisoners. I: Annals of the American Academy of Political and Social Service, s. 99 ff.

Ugelvik, T. (2011): Fangenes friheter. Makt og motstand i et norsk fengsel. Oslo: Universitetsforlaget. 